\title{
TOURIST PREFERENCES IN EAST FLORES DISTRICT
}

\author{
${ }^{1}$ Ina Veronika Ginting, S.Sos., M.I.Kom \\ ${ }^{2}$ Endang Komesty Sinaga, S.S, MM.Par \\ ${ }^{3}$ Drs. Rachmat Muljawan, MM.Par \\ ${ }^{4}$ Dina Elfrida Rajagukguk \\ ${ }^{5}$ Gebi Desiani \\ ${ }^{6}$ Renaldy Dwi Muharram \\ ${ }^{7}$ Fransiskus Henry Setiawan \\ ${ }^{8}$ Oktaviyani Yusnida \\ ${ }^{9}$ Adinda Adilla Farameutia \\ 1,2,3,4,5,6,7,8 Sekolah Tinggi Pariwisata Bandung \\ Bandung, Indonesia \\ genglarantuka@gmail.com
}

\begin{abstract}
East Flores Distric is one of district at East Nusa Tenggara that has natural and cultural tourist attractions potential. Based on the data from Swisscontact in 2013 there is an increasing number of international tourists visiting each years, but in the last year 2014, the target of tourists visiting is not as expected. They visited East Flores District in less than two days. Therefore, to meet the target of tourists visiting at East Flores District, an analysis of tourist preferences need to conduct in order to extend the tourists' length of stay at East Flores. East Flores District has the main spiritual event as tourist attraction potential that is located in Larantuka as the capital city of East Flores namely is Samana Sancta as an Easter Celebration (Holy Week) due of Larantuka is broadly known as a place for Catholic Pilgrims. Besides that Larantuka also has the natural and cultural beauty that have to be developed as one of tourism destination. This becomes a challenge for the stakeholders of East Flores to attract people to travel to Larantuka beside than Semana Sancta event motive. The research method is applied with descriptive quantitative methode and design with descriptive analysis, and use Chi Square for the analysis technique. Based on datas and analysis during the research, the result of analysis, that tourist preferences in East Flores can be determined from : (1)tourist profile aspect dominated by domestic and international tourists, (2)Structure preferences aspect based on destination option, information availability, family and relative recommendation, norms and culture reason, (3)Decision making of visiting East Flores determined by tourist's internal and external motivation.
\end{abstract}

The conclusion, tourist preference motivated from their internal motivation, which is pilgrim activities.

Keywords: Preferences; East Flores District; Tourists Profile; Structure Preferences; Internal Decisions; External Decisions

\section{Introduction}

Tourism is one of the important sectors economies in Indonesia, which became one of the greatest contributions to national revenue. The development of tourism has been proven to have a positive effect with major changes in society. Economically, tourism gives impacts on business decisions and employment opportunities, increasing per capita income and increasing in foreign exchange.

East Flores district is an archipelagoic district in East Nusa Tenggara province, which includes mainland East Flores district, Adonara and Solor Island. This geographical character turns out to load a resource that is so rich in the form of starfish archeology, cultural history and art, flora and fauna, as well as dense maritime potential. Generally, people of East Flores are fishermen and farmers to exploit the potential of existing natural resources. 
Geographically, East Flores district is located in parts of the eastern island of Flores, and it is easy to reach from any direction, along with the increasingly open and the development of the telecommunications network and infrastructure support in the communications sector, including the already open flight path from Kupang to Larantuka, network services PT PELNI that stop Larantuka from various major cities in Indonesia, ferry services from Kupang with a frequency almost every day, as well as land transport flows that connect all districts on the island of Flores. Other public facilities services such as tourism amminities and accesibility there are : accommodation / lodging, restaurants, interisland sea transport, post and telecommunications, banks, hospitals support the East Flores as the potential tourism destination. East Flores District has many potential attractions that can be developed to increase the visitors especially the samana sancta commemoration every year as the main turist attraction with the catholic pilgrame activities purpose at Larantuka. As an alternative destination that is spiritual travel. The spiritual tourism attraction in this area is on the town of Larantuka. In addition to the existing spiritual, East Flores district also has a variety of attractions such as the natural beauty and culture that needs to be developed as a tourist attraction. This has become a challenge for East Flores district stakeholders how to bring tourists outside Semana Sancta activities, so that the number of tourist arrivals could increase.

Based on the results of interviews investigators with the East Flores District Government Tourism Office, the number of visitors of tourist arrivals in 2015 is expected to increase from the previous year, counted to 23,271 travelers consisting of 271 foreign tourists and 23,000 domestic tourists.
Anchorage cruise in East Flores is a positive impact, based on the data the frequent of cruise tourists who visit East Flores for tourism because it becomes a good opportunity to increase the number of tourists. It is just need to know the preference of tourist who visit East Flores so that can be offer the package tour as a tourism product beside pilgrim tourist attraction.

According Swisscontact research (2013) the tourists length of stay beside the spiritual Semana Sancta commemoration is less than two days. The figure below is the following data of tourists' length of stay East Flores district.

\section{FIGURE 1}

\section{TOURISTS' LENGTH OF STAY IN} EAST FLORES

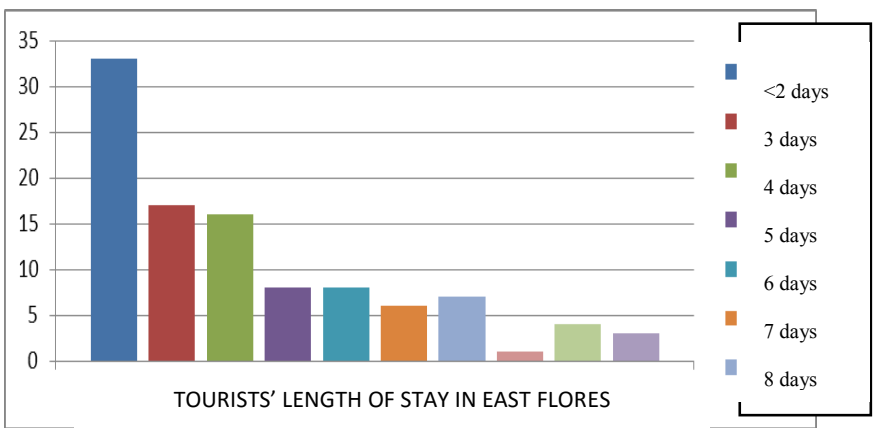

Source: Data Swisscontact 2013

Therefore, an analysis is needed to determine the motivation of tourists to visit East Flores district and how to increase the length of stay in East Flores. Various existing tourism potential in East Flores district expected to attract tourists to visit so as to increase the length of tourist visits by introducing a tourist attraction owned by East Flores district in accordance with the desire of tourists.

In order to provide the best service for tourists, the travel services provider should understand the preferences of tourists. According to Nursusanti (2005), "traveler 
Geographically, East Flores district is located in parts of the eastern island of Flores, and it is easy to reach from any direction, along with the increasingly open and the development of the telecommunications network and infrastructure support in the communications sector, including the already open flight path from Kupang to Larantuka, network services PT PELNI that stop Larantuka from various major cities in Indonesia, ferry services from Kupang with a frequency almost every day, as well as land transport flows that connect all districts on the island of Flores. Other public facilities services such as tourism amminities and accesibility there are : accommodation / lodging, restaurants, interisland sea transport, post and telecommunications, banks, hospitals support the East Flores as the potential tourism destination. East Flores District has many potential attractions that can be developed to increase the visitors especially the samana sancta commemoration every year as the main turist attraction with the catholic pilgrame activities purpose at Larantuka. As an alternative destination that is spiritual travel. The spiritual tourism attraction in this area is on the town of Larantuka. In addition to the existing spiritual, East Flores district also has a variety of attractions such as the natural beauty and culture that needs to be developed as a tourist attraction. This has become a challenge for East Flores district stakeholders how to bring tourists outside Semana Sancta activities, so that the number of tourist arrivals could increase.

Based on the results of interviews investigators with the East Flores District Government Tourism Office, the number of visitors of tourist arrivals in 2015 is expected to increase from the previous year, counted to 23,271 travelers consisting of 271 foreign tourists and 23,000 domestic tourists.
Anchorage cruise in East Flores is a positive impact, based on the data the frequent of cruise tourists who visit East Flores for tourism because it becomes a good opportunity to increase the number of tourists. It is just need to know the preference of tourist who visit East Flores so that can be offer the package tour as a tourism product beside pilgrim tourist attraction.

According Swisscontact research (2013) the tourists length of stay beside the spiritual Semana Sancta commemoration is less than two days. The figure below is the following data of tourists' length of stay East Flores district.

\section{FIGURE 1}

\section{TOURISTS' LENGTH OF STAY IN} EAST FLORES

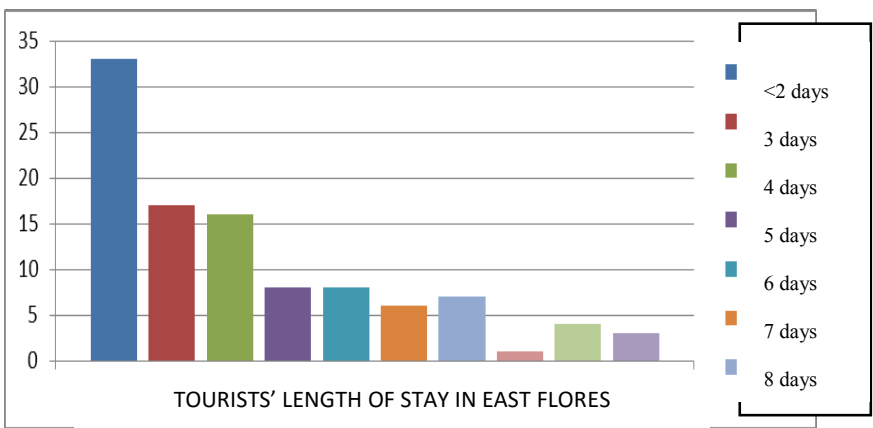

Source: Data Swisscontact 2013

Therefore, an analysis is needed to determine the motivation of tourists to visit East Flores district and how to increase the length of stay in East Flores. Various existing tourism potential in East Flores district expected to attract tourists to visit so as to increase the length of tourist visits by introducing a tourist attraction owned by East Flores district in accordance with the desire of tourists.

In order to provide the best service for tourists, the travel services provider should understand the preferences of tourists. According to Nursusanti (2005), "traveler 
preferences come from the desire and needs of tourists to the tourism product on offer in making tour". Currently the tourist motivation and needs to the tourism product is more complex, dinamic, and insist to the quality that is associated with the principles of sustainable development. The tourist destination area must be competable to all the changing demands by always concern to the advice of the various interested participants especially for the differennces of tourists preverence in choosing the tourist attraction.

According to Luiz Moutinho (2012: 120) "preference is the structure of the desire of tourists against the destination depending on factors such as the additional information that is designed, effective decision on the destination can be expected to change the times of a longer visit. Among these factors, incorporated with the influence of internal factors in the environment where there are norms and cultural values, desires groups, family, financial status, and social levels. All of it is determined by the structure of preferences that will affect the tourism product evaluation. Each determinants of preference structures composed of concepts such as personality, lifestyle, and motivation."

Motivation can be defined as an awareness of the needs of psychology that is influenced by genetic factors, experiences and situations. Trough this research of tourist preferences is expected to reveal the tourists motivation and the influence decision in East Flores. Therefore, researchers are interested in conducting research titled "Tourist Preferences in East Flores District".

\section{PURPOSE OF THE STUDY}

a. Knowing the profile of domestic and foreign tourists in East Flores.

b. Knowing the structure of domestic tourist preferences and foreign in East Flores.

c. Knowing the internal decision of domestic and foreign tourists in East Flores.

d. Knowing the decision of external domestic and foreign tourists in East Flores.

Preferences are formed by perception of the product according to the stages of information processing (Mowen and Minor in Sumarwan, 2012) Schiffman and Kanuk (2004) in Sumarwan (2012) defines preference as the way a person sees the world around. Two individuals may receive the same stimulus in the same conditions, but how to process the stimulus will depend on the needs, values and expectations of the individual. Consumer preferences related to consumer expectations what product they really like. Preference is a things that have to be first and priority than others, priorities, preferences, tendencies, and more preferable (Ministry of Education, 2001).

Based on the notions above, it can be concluded that the preference is a component which plays an important role that should take priority to support the changing demands of the various interested parties, especially tourists who have different preferences in visiting a destination.

According to Luiz Moutinho (2012: 120) "The decision process may be studied as a sequence of conflict situations constituting a decision process are those that precede the choice and are necessary to explain what is chosen. This decision results in a psychological predisposition in terms of intension towards the buying act". The result 
of these decisions tends to psychological in buying. Tourists decision based on the illustration that they felt, destination promotion, a past experience, overview of potential destinations, travel intermediaries, advice or social interaction. The decision process is determined by conscious background of tourists that includes the formation of beliefs and illustration, holiday evaluation concept, and the decision to travel.

There are many factors that influence tourists motivation, according to John Swarbrooke \& Susan Horner (1996) some of which are illustrated in Figure 2 below, regarding internal and external factors that affect the decision to travel. Here are the internal and external factors that affect the travel decision.

\section{FIGURE 2}

\section{FACTORS AFFECTING VACATION IN DECISION MAKING}

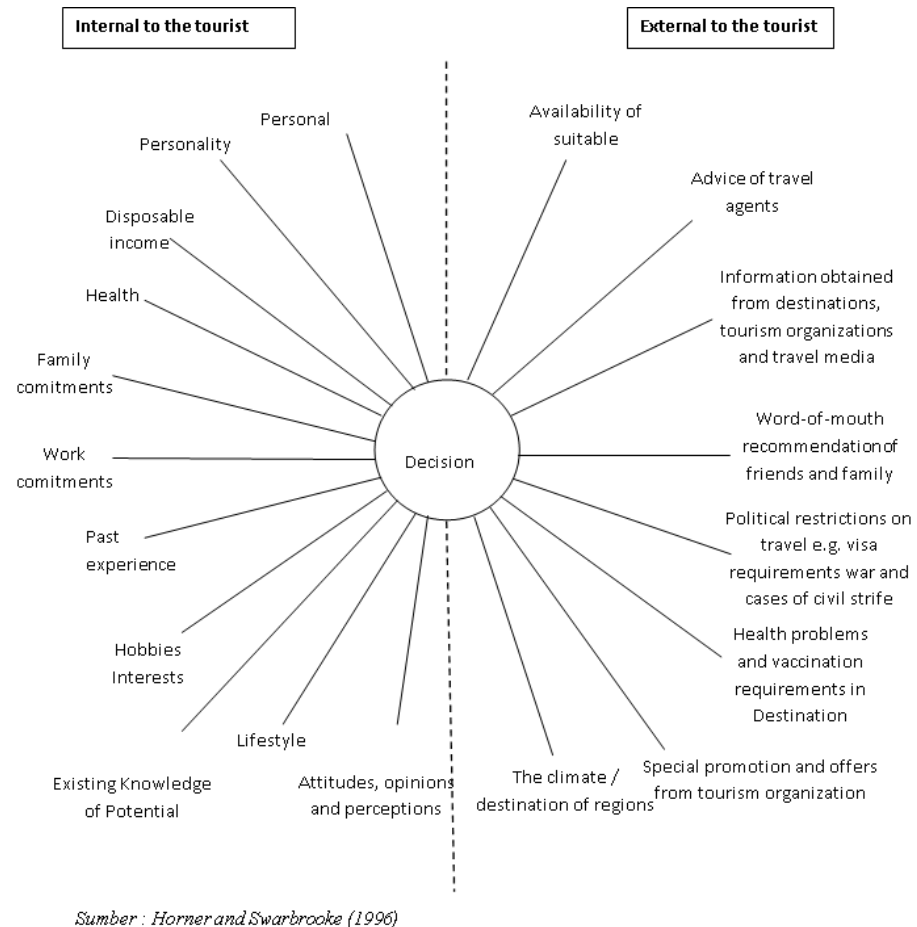

Schmoll makes a decision model of sightseeing travel that should be thoroughly based on the tourists motivations, needs and expectations in a personal and social. The decision process of travel consists of four fields that affect the final decision, namely stimulant travel, internal variables, external variables and characteristics of the tourist destination.

\section{Travel Motivation}

Travel motivation is an important thing for tourists to take a decision. tourist motivation is very basic thing because motivation is the trigger of the travel process, although the motivation is often not realized by the tourists themselves (Sharpley, 1994).

The analysis of motivation is more important if associated with tourism, in which human behavior is influenced by a variety of motivations. Basically, travel is motivated by several things to encourage the travel. Motivation can be defined as an awareness of the needs by psychology that is influenced by genetic factors, experiences and situations. After that the structure of traveler preferences, through to know the factors of decision-making and purchasing factor.

According to Mc Intosh and Goeldner in Cooper (1993: 124-125) suggests that traveler's motivation can be grouped into four, namely:

1. Physical motivation, is done for the purposes of healthy, body refreshing, exercise, and enjoy leisure time with the aim of reducing the pressure on regular activities.

2. Cultural motivation is done with the aim want to know the culture of an area, as a lifestyle, music, arts, dances, and things that are unique and original of a culture.

3. Interpersonal Motivation, such like seeing friends, relatives and spiritual enlightenment. 
4. Status or prestige that is motivation to do for education, science, recognition or attention of others.

Theory of the relevany motivation in this reasearch is used in this study as related in courage factors for the tourists visit East Flores. The motivation will affect how the product components impress the tourist preferences in East Flores.

\section{Finding and dicscussion}

\section{Tourist Profile}

\begin{tabular}{|l|l|l|l|l|}
\hline \multirow{2}{*}{ No } & \multicolumn{4}{|c|}{ Tourist Origin } \\
\cline { 2 - 5 } & $\begin{array}{c}\text { Domestic } \\
\text { Tourist }\end{array}$ & \multicolumn{1}{|c|}{ Persentage } & $\begin{array}{c}\text { Foreign } \\
\text { Tourist }\end{array}$ & Persentage \\
\hline 1. & Kupang & $29 \%$ & Timor Leste & $35,3 \%$ \\
\hline 2. & Jakarta & $17 \%$ & Philippine & $23,5 \%$ \\
\hline 3. & Bandung & $13 \%$ & Australia & $11,8 \%$ \\
\hline 4. & Maumere & $9 \%$ & Spain & $11,8 \%$ \\
\hline 5. & Yogyakarta & $7 \%$ & $\begin{array}{l}\text { United } \\
\text { State }\end{array}$ & $5,9 \%$ \\
\hline 6. & Ende & $3 \%$ & Belgium & $5,9 \%$ \\
\hline 7. & Lembata & $3 \%$ & Japan & $5,9 \%$ \\
\hline
\end{tabular}

Domestic and foreign tourists who visited East Flores district do not dominate between men and women also the work that dominates is private employees, and domestic tourists who visit the East Flores district come from Kupang while the foreign tourists come from Timor Leste which can also be used as a target of potential market.

\section{Preference Structures}

\begin{tabular}{|c|c|c|c|c|}
\hline \multirow[t]{2}{*}{ No } & \multicolumn{4}{|c|}{ Structure Preference } \\
\hline & $\begin{array}{l}\text { Domestic } \\
\text { Tourist }\end{array}$ & Percentage & $\begin{array}{l}\text { Foreign } \\
\text { Tourist }\end{array}$ & Percentage \\
\hline 1 & $\begin{array}{l}\text { Information } \\
\text { on the } \\
\text { adequacy of } \\
\text { East Flores } \\
\text { district is } \\
\text { enough }\end{array}$ & $70 \%$ & $\begin{array}{l}\text { Information } \\
\text { on the } \\
\text { adequacy of } \\
\text { East Flores } \\
\text { district isnt } \\
\text { enough }\end{array}$ & $64.7 \%$ \\
\hline 2 & $\begin{array}{l}\text { East Flores } \\
\text { district as the } \\
\text { election of } \\
\text { the right } \\
\text { destination }\end{array}$ & $95 \%$ & $\begin{array}{l}\text { East Flores } \\
\text { district as the } \\
\text { election of } \\
\text { the right } \\
\text { destination }\end{array}$ & $94.1 \%$ \\
\hline 3 & $\begin{array}{l}\text { Norms and } \\
\text { culture is a } \\
\text { reason to } \\
\text { visit Ke East } \\
\text { Flores } \\
\text { district }\end{array}$ & $87 \%$ & $\begin{array}{l}\text { Norms and } \\
\text { culture is a } \\
\text { reason to } \\
\text { visit East } \\
\text { Flores } \\
\text { district }\end{array}$ & $88.2 \%$ \\
\hline 4 & $\begin{array}{l}\text { Family or } \\
\text { friends is not } \\
\text { a reason to } \\
\text { visit East } \\
\text { Flores } \\
\text { district }\end{array}$ & $58 \%$ & $\begin{array}{l}\text { Family or } \\
\text { friends is } \\
\text { thereason to } \\
\text { visit East } \\
\text { Flores } \\
\text { district }\end{array}$ & $58.8 \%$ \\
\hline
\end{tabular}

Based on the data obtained, the tourists said that the information obtained regarding the East Flores district already provide sufficient information, but the tourists argued that the information provided has not been given enough information. Norms and culture contained in East Flores is a tourist's reason to travel to the East Flores District. Motivation is also supported by the strength of cultural attractions owned East Flores District. 


\section{Internal Decision}

\begin{tabular}{|c|c|c|c|c|c|}
\hline No & $\begin{array}{l}\text { Internal } \\
\text { Decision }\end{array}$ & $\begin{array}{l}\text { Domestict } \\
\text { Tourist }\end{array}$ & $\begin{array}{l}\text { Perce } \\
\text { ntage }\end{array}$ & $\begin{array}{l}\text { Foreign } \\
\text { Tourist }\end{array}$ & $\begin{array}{l}\text { Perce } \\
\text { ntage }\end{array}$ \\
\hline 1. & Income & $\begin{array}{l}\text { Rp. } \\
1.000 .001- \\
\text { Rp. } \\
3.000 .000\end{array}$ & $39 \%$ & $\begin{array}{l}\text { Rp.3.000.0 } \\
01-\text { Rp. } \\
5.000 .000\end{array}$ & $88,2 \%$ \\
\hline 2. & $\begin{array}{l}\text { Expenditu } \\
\text { re }\end{array}$ & $\begin{array}{l}\text { Rp. } \\
1.000 .001- \\
\text { Rp. } \\
3.000 .000\end{array}$ & $43 \%$ & $\begin{array}{l}\text { Rp.3.000.0 } \\
01-\text { Rp. } \\
5.000 .000\end{array}$ & $35,3 \%$ \\
\hline 3. & $\begin{array}{l}\text { Tourists } \\
\text { healthy }\end{array}$ & Yes & $71 \%$ & Yes & $70,6 \%$ \\
\hline 4. & $\begin{array}{l}\text { Decision } \\
\text { Making } \\
\text { arranged } \\
\text { the trip }\end{array}$ & myself & $54 \%$ & myself & $88,2 \%$ \\
\hline 5. & $\begin{array}{l}\text { Free time } \\
\text { in a year } \\
\text { that } \\
\text { tourist } \\
\text { got from } \\
\text { company }\end{array}$ & $\begin{array}{l}\text { more than } \\
12 \text { days }\end{array}$ & $76 \%$ & $\begin{array}{l}\text { more than } \\
12 \text { days }\end{array}$ & $82,4 \%$ \\
\hline 6. & $\begin{array}{l}\text { Have } \\
\text { been to } \\
\text { East } \\
\text { Flores } \\
\text { District } \\
\text { before }\end{array}$ & Never & $56 \%$ & Never & $100 \%$ \\
\hline 7. & $\begin{array}{l}\text { Ideal } \\
\text { Time to } \\
\text { Visit East } \\
\text { Flores } \\
\text { District }\end{array}$ & 5-7 days & $35 \%$ & $\begin{array}{l}\text { 3-5 days \& } \\
5-7 \text { days }\end{array}$ & $29,4 \%$ \\
\hline 8. & $\begin{array}{l}\text { Intereste } \\
\mathrm{d} \text { Activity } \\
\text { in East } \\
\text { Flores } \\
\text { District }\end{array}$ & $\begin{array}{l}\text { Religion } \\
\text { Activity }\end{array}$ & $72 \%$ & Adventure & $47,1 \%$ \\
\hline 9. & $\begin{array}{l}\text { Activity } \\
\text { to do in } \\
\text { East } \\
\text { Flores } \\
\text { District }\end{array}$ & $\begin{array}{l}\text { Religion } \\
\text { Activity }\end{array}$ & $62 \%$ & $\begin{array}{l}\text { Religion } \\
\text { Activity }\end{array}$ & $47,1 \%$ \\
\hline
\end{tabular}

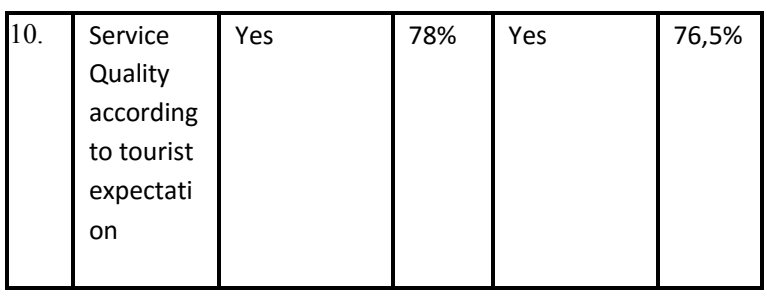

\begin{tabular}{|c|c|c|c|}
\hline No & $\begin{array}{c}\text { Tourist } \\
\text { Motivation }\end{array}$ & $\begin{array}{c}\text { Domestic } \\
\text { Tourist } \\
\text { (Percentage) }\end{array}$ & $\begin{array}{c}\text { Foreign } \\
\text { Tourist } \\
\text { (Persentage) }\end{array}$ \\
\hline 1. & Healthy & $10 \%$ & $18 \%$ \\
\hline 2. & Body Refresher & $19 \%$ & $35 \%$ \\
\hline 3. & Sport & $9 \%$ & $18 \%$ \\
\hline 4. & Recreation & $47 \%$ & $53 \%$ \\
\hline 5. & $\begin{array}{l}\text { Reducing the } \\
\text { pressure of routine } \\
\text { activites }\end{array}$ & $33 \%$ & $41 \%$ \\
\hline 6. & $\begin{array}{l}\text { Traditional } \\
\text { Culture }\end{array}$ & $70 \%$ & $82 \%$ \\
\hline 7. & Life Style & $52 \%$ & $65 \%$ \\
\hline 8. & Traditional Music & $35 \%$ & $29 \%$ \\
\hline 9. & Art & $41 \%$ & $41 \%$ \\
\hline 10. & Visiting Friends & $29 \%$ & $11 \%$ \\
\hline 11. & Visiting family & $83 \%$ & $11 \%$ \\
\hline 12. & Spiritual Recovery & $83 \%$ & $76 \%$ \\
\hline 13. & Travelling & $60 \%$ & $11 \%$ \\
\hline 14. & Official Duty & $11 \%$ & $11 \%$ \\
\hline 15. & Education & $19 \%$ & $75 \%$ \\
\hline
\end{tabular}

Motivation of tourists' arrival is dominated by the motivation of spiritual enlightenment, while the foreign tourists are dominated by 
regional cultural motivation. Additionally, time of holiday also affect to how much they spend on travel. The results of the data indicate the time it takes travelers to travel to East Flores district should be done for 5-7 days. It can be seen as a good opportunity, so that stakeholders can take this opportunity to increase tourist arrivals by offering a tourist attraction that has the potential to be developed and one of the attractions that have attracted tourists that is religious activities and adventure.

\section{External Decision}

\begin{tabular}{|l|l|l|l|l|}
\hline $\begin{array}{l}\text { External } \\
\text { Decision }\end{array}$ & $\begin{array}{l}\text { Domestic } \\
\text { Tourist }\end{array}$ & Percentage & $\begin{array}{l}\text { Foreign } \\
\text { Tourist }\end{array}$ & Percentage \\
\hline $\begin{array}{l}\text { Tourist with } \\
\text { tour package }\end{array}$ & No & $92 \%$ & Yes & $52,9 \%$ \\
\hline $\begin{array}{l}\text { Tourist get } \\
\text { information } \\
\text { from Travel } \\
\text { Agent }\end{array}$ & No & $92 \%$ & Yes & $52,9 \%$ \\
\hline $\begin{array}{l}\text { Information } \\
\text { Media that } \\
\text { used }\end{array}$ & Internet & $74 \%$ & Internet & $70,6 \%$ \\
\hline $\begin{array}{l}\text { Infromation } \\
\text { from family }\end{array}$ & Yes & $73 \%$ & Yes & $82,4 \%$ \\
\hline $\begin{array}{l}\text { Free Pass } \\
\text { Visa }\end{array}$ & Yes & $67 \%$ & No & $52,9 \%$ \\
\hline $\begin{array}{l}\text { Health } \\
\text { Condition in } \\
\text { destination } \\
\text { reason }\end{array}$ & Yes & $52,9 \%$ & Yes & $67 \%$ \\
\hline limate & & No & $70,6 \%$ \\
\hline
\end{tabular}

The most visited place as nature attractions is Weri beach and the most visited place as cultural tourism attractions is Chapels, like Chapel of Tuan Ana and Tuan Ma. Based on the observation of the researchers, the natural and cultural attractions located in East Flores district are still many who have not visited by tourists because of the lack of information and did not already know tourist attraction that also has potential. From the aspect of accessibility indicates that overall is good. However, the absence of public transportation / special to go to several attractions as well as road conditions and the direction boards are still not good. When viewed from the aspect of amenities availability consisting of hotel, café-restaurant and gift shop still cannot meet the needs of travelers. Availability of the hotel is still very minimal and standardized hotels that do not fit. One of the shortcomings that still look difficult is to find a restaurant as well as the small number of gift shop, while gift shop is one of the important sectors to support this place because generally travellers will bring a souvenir from a place they visit.

Domestic tourists who visit the East Flores district generally do not use the services of travel agents, while the foreign tourists dominantly use the services of travel agents. Still at least the number of travel agents in East Flores makes business travel agent services less active role in the development of tourism in East Flores, so we need the readiness of the stakeholders to be able to sell a travel package to market domestic and foreign markets. 
FIGURE 3 THE RESULT OF CHI-SQUARE ANALYSIS

\begin{tabular}{|l|l|l|}
\hline \multicolumn{2}{|l|}{ The result of chi-square analysis } \\
\cline { 2 - 3 } & \multicolumn{2}{|c|}{ Percentage } \\
\cline { 2 - 3 } & Domestic Tourist & Foreign Tourist \\
\hline Tourist's Profile -> Preference Stucture & $39,77 \%$ & $67,6 \%$ \\
\hline Tourist's Profile -> Internal Decision & $58,5 \%$ & $64,8 \%$ \\
\hline Preference Stucture -> Internal Decision & $31,6 \%$ & $49,1 \%$ \\
\hline Tourist's Profille -> External Dedision & $43,6 \%$ & $61 \%$ \\
\hline Preference Structure -> External Decision & $10,8 \%$ & $61,7 \%$ \\
\hline
\end{tabular}

Based on analysis test results on the association of some indicators as a representative of the profile with the structure of domestic tourists' preferences, it obtained significant results amounted to $39.77 \%$, while the foreign tourists showed a significantly higher rate is $67.6 \%$. These results have shown the existence of a significant relationship between profiles and preference structures.

Based on the results analysis test about the interrelatedness of some indicators as a representative of the profile and the internal decision of domestic tourists obtained yield was $58.5 \%$, while foreign tourists obtained yield was $64.8 \%$. In addition, based on the results analysis test about the interrelatedness of several indicators as representatives of the preference structures with internal decisions of domestic tourists obtained yield was $31.6 \%$, while foreign tourists showed a significantly higher rate is $49.1 \%$. These results indicate that there is a significant relationship between the structure of preferences and profile with preference structures with internal decisions.

Based on the results analysis test about the interrelatedness of some indicators as a representative of the profile with external decision of domestic tourists obtained yield by $43.6 \%$ while foreign tourists obtained yield by $61, \%$. While based on the results analysis test about the interrelatedness of some indicators as representatives of the preference structures with external decision of domestic tourists, the result amounted to $18.8 \%$, while foreign tourists showed a significantly higher rate is $61.7 \%$. These results indicate that there is a significant relationship between profile with external decision and preference structure with external decision.

\section{Conclusion \& Recommendation}

Based on the results that it needs to be known the tourist motivation of visiting the East Flores district to analyze the tourists preference. Therefore, the conclusions that can be described are as follows, Tourist Profile mostly coming from Kupang and Timor leste that should be a good opportunity to be a target potensial.

Preference structure dominated of Norms and culture contained in East Flores is a tourist's reason to travel to the East Flores District because East Flores culture and norms are very unique and attractive.

Internal decision dominated of motivation of spiritual enlightenment and regional cultural motivation, tourists visit to East Flores for the pilgrimage and follow the semana sancta commemoration, and also as East Flores have a unique cultures which can attract foreign tourists.

External decision dominated of visited place as nature attractions because East Flores has unspoiled natural beauty that not many untouched, and visited place as cultural tourism attractions such as chapels , 
From the aspect of accessibility indicates that overall is good, it's know that East Flores accessible by airplane, cruise, ship and bus.

It is, than suggested tourist preference in East Flores with there needs to be a promotional tool to facilitate the tourists and get the information through social media, print media and internet, as well as the willingness Tourist Information Center which is more active in serving the tourists who to visit East Flores

The role of the travel agent to arrange tour packages to East Flores district to meet the needs and tourist motivation who visit East Flores

The need to attention and awareness tourism government office to manage the standardization of tourism business in East Flores, The need for cooperation between stakeholders such as communities, businesses and government office to develop of quality human resources to implement a tourism awareness to the local community

\section{REFERENCES}

[1] Damayanti, A. D. (2012). Analisis Karakteristik Wisatawan dan persepsi Wisatawan mengenai Fasilitas Wisata Di kampung Batu Malakasari Kab Bandung. Bandung: Bandung.

[2] Dwiputra, R. (2013). Preferensi Wisatawan Terhadap Sarana Wisata di Kawasan Wisata Alam Erupsi Merapi. Jurnal Perencanaan Wilayah dan Kota, 35-48.

[3] Hanifah,M. (2013, September 9). lifestyleokezone. Retrieved from okezone web site: http://lifestyle.okezone.com/read/2013/09/09/407/8 63025/4-kepribadian-wisatawan-saat-pelesir-yangmanakah-anda

[4] Ismayanti. (2010). Pengantar Pariwisata. Jakarta: Grasindo.
[5] K., M. A. (2014). Analisis faktor-faktor yang mempengaruhi kunjungan wisatawan di pantai cahaya, weleri, kabupaten kendal. Semarang.

[6] Khoiron,R. (2013, June 26). http://jejakwisata.com/tourism-studies/planningand-development/120-peran-strategis-daerahtransit-dalam-industripariwisata.html.Retrievedfrom Jejakwisata.com: http://jejakwisata.com/tourism-studies/planningand-development/120-peran-strategis-daerahtransit-dalam-industri-pariwisata.html

[7] Kotler P, Bowen J.T, Makens J.C. (2010). Marketing for Hospitality and Tourism. New Jersey: Pearson Education, Inc.

[8] LERI, I. A. (2011). Dampak pengeluaran wisatawan terhadap perkembangan sektor ekonomi di provinsi bali. Denpasar.

[9] Mizan, A.(2014, November 14).Makalah Pengambilan Keputusan Dalam Melakukan Perjalanan Wisata. Surabaya.

[10] Moutinho, L. (2012). In Strategic Management in Tourism. Wallingford, Oxon, UK ; New York, N.Y.

[11] Nurhidayati, S. E. (2011). Analisis Pola Belanja Wisatawan Kelompok di Kota Batu. Bina Wisata Fisip, 328-335.

[12] Ryan, C. (2001). In The Tourist Experience. Oxford: Linacre House.

[13] Samsudin Sulaiman, K. (2013). Pengantar Statistika Pariwisata Aplikasinya dalam bidang: Pariwisata, Usaha Perjalanan, dan Perhotelan. Bandung: Alfabeta, cv.

[14] Sudjana. (2001). In Metode Statistika. Bandung: Tarsito.

[15] Sugiyono. (2009). In Metode Penelitian Administrasi Dilengkapi dengan Metode R\&D. Bandung: Alfabeta.

[16] Susan Horner, J. s. (1999). Consumenr Behaviour in Tourism. Linacre House, Jordan Hill, Oxford: $A$ division of reed Eduicational and Professional.

[17] SwissContact. (2013). Intergrated Tourism Development Plan. Flores: SwissContact.

[18] TOULE, R. (2015). Preferensi wisatawan nusantara terhadap sarana akomodasi di Provinsi Bali. Bali. 
of these decisions tends to psychological in buying. Tourists decision based on the illustration that they felt, destination promotion, a past experience, overview of potential destinations, travel intermediaries, advice or social interaction. The decision process is determined by conscious background of tourists that includes the formation of beliefs and illustration, holiday evaluation concept, and the decision to travel.

There are many factors that influence tourists motivation, according to John Swarbrooke \& Susan Horner (1996) some of which are illustrated in Figure 2 below, regarding internal and external factors that affect the decision to travel. Here are the internal and external factors that affect the travel decision.

\section{FIGURE 2}

\section{FACTORS AFFECTING VACATION IN DECISION MAKING}

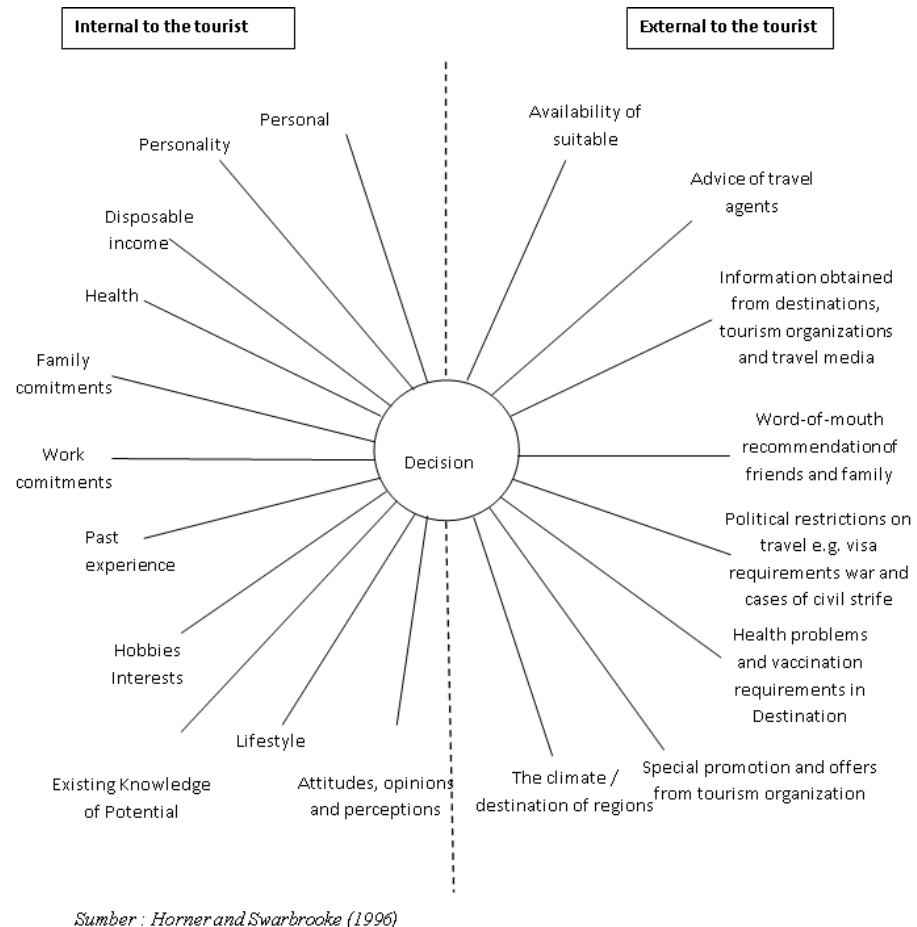

Schmoll makes a decision model of sightseeing travel that should be thoroughly based on the tourists motivations, needs and expectations in a personal and social. The decision process of travel consists of four fields that affect the final decision, namely stimulant travel, internal variables, external variables and characteristics of the tourist destination.

\section{Travel Motivation}

Travel motivation is an important thing for tourists to take a decision. tourist motivation is very basic thing because motivation is the trigger of the travel process, although the motivation is often not realized by the tourists themselves (Sharpley, 1994).

The analysis of motivation is more important if associated with tourism, in which human behavior is influenced by a variety of motivations. Basically, travel is motivated by several things to encourage the travel. Motivation can be defined as an awareness of the needs by psychology that is influenced by genetic factors, experiences and situations. After that the structure of traveler preferences, through to know the factors of decision-making and purchasing factor.

According to Mc Intosh and Goeldner in Cooper (1993: 124-125) suggests that traveler's motivation can be grouped into four, namely:

1. Physical motivation, is done for the purposes of healthy, body refreshing, exercise, and enjoy leisure time with the aim of reducing the pressure on regular activities.

2. Cultural motivation is done with the aim want to know the culture of an area, as a lifestyle, music, arts, dances, and things that are unique and original of a culture.

3. Interpersonal Motivation, such like seeing friends, relatives and spiritual enlightenment. 